УДК 330.36

DOI: https://doi.org/10.37320/2415-3583/7.8

Дергалюк Б.В.

кандидат економічних наук, доцент кафедри економіки і підприємництва, Національний технічний університет України «Київський політехнічний інститут імені Ігоря Сікорського» ORCID: https://orcid.org/0000-0001-8791-9121

\title{
СТРУКТУРНІ ЕЛЕМЕНТИ ЕКОНОМІКИ ТА ЇХ ПРОПОРЦЇ̈
}

\begin{abstract}
У статті досліджено сутність структури економіки, визначено ї̈ значення щзодо динаміки та спрямування розвитку економіки країни. Встановлено, щуо вищезазначена структура є досить складною та включає сукупність відносно взаємопов'язаних елементів, кожен з яких має відмінну роль, але задіяний для досягнення спільних иілей, при иььому зберігає незмінність своїх основних властивостей під впливом зовнішніх та внутрішніх факторів. Серед таких елементів визначено відтворювальну, секторально-галузеву, інституціональну, територіальну, зовнішньоекономічну, секторальну, технологічну та соціальну структури. Стан зазначених елементів структури економіки визначається певними пропориіями. Саме иุі пропориії формують структурну модель економіки тієі чи іншої країни. Дисбаланси, щзо виникають у изих пропориіях, призводять до кризи структури економіки країни, але зазначені пропориї зазнають постійних змін, щчо свідчить про динаміку структури. Ці зміни є різними, щзо приводить до структурних зрушень та формування нової структури економіки. Саме тому державна економічна політика країни має будуватися з урахуванням пропориій в елементах структури економіки та відповідним чином впливати на їх зміну задля побудови оптимальної структури економіки, яка б сприяла не лише покращенню економічних показників порівняно з попереднім періодом, але й досягненню потенційно можливого рівня.
\end{abstract}

Ключові слова: структура економіки, елементи структури економіки, пропориї структури економіки.

Постановка проблеми. Метою написання наукової статті є визначення основних елементів структури економіки та пропорцій, які визначають стан зазначених елементів.

Аналіз останніх досліджень і публікацій. Питанням структури економіки присвячені праці багатьох провідних учених. Серед них слід назвати таких, як В.Г. Бодров [1], О.І. Клімова [2], Л.В. Шинкарук [3], І.А. Бев3 [3], О.П. Тищенко [4], Г.М. Поченчук [5].

Однак визначенню складових елементів структури економіки та основних пропорцій, що визначають їх, приділено недостатньо уваги.

Мета статті полягає у дослідженні структури економіки, визначенні іiі значення щодо динаміки та спрямування розвитку економіки країни.

Виклад основного матеріалу. Розвиток економічної системи перебуває під постійним впливом низки внутрішніх та зовнішніх чинників, які визначають його спрямування та динаміку. Під впливом вищезазначених чинників формується структура економіки, тобто сукупність галузей, сфер господарської діяльності, взаємопов'язаних суспільним поділом праці, що охоплює виробництво благ, обмін ними, розподіл і споживання їх, а також різноманітні організаційні форми та інституції, в яких відбуваються господарські процеси, економічна діяльність людей за певним способом організації господарського життя суспільства задля вирішення його ключових проблем [1].

Таким чином, структура економіки, як будьяка інша структура, $€$ сукупністю відносно взаємопов' язаних елементів, кожен з яких має відмінну роль, але задіяний для досягнення спільних цілей, при цьому зберігає незмінність своїх основних властивостей під впливом зовнішніх та внутрішніх факторів.

Як зазначено в роботі [2], структура економіки будь-якого виду дає змогу встановити іiі пропорції, які багато в чому визначають їі стан, вплив на соціальні аспекти в суспільстві, становище країни у світовій господарській системі. Зміна в структурі економіки є наслідком структурних змін, які виникають через зміну окремих елементів i, відповідно, їх ролі в системі, а також через зміну взаємозв'язків елементів та їх взаємовпливу.

Отже, кінцева структурна модель тієї чи іншої економіки формується сукупністю різнорівневих економічних пропорцій. Дисбаланси, що виникають у вищезазначених пропорціях, приводять до макроекономічних диспропорцій та кризи структури економіки країни.

У науковій літературі виділяють різні структури, що є складовими елементами структури економіки. Так, у джерелах [1-5] зазначено, що зіставними структурними елементами та зрізами економічної структури можуть бути галузі (галузева структура), регіони (регіональна структура), технологічні уклади (технологічна структура) тощо.

Підходи до визначення складових елементів структури економіки дають можливість детально аналізувати їі в різних аспектах. Однак водночас можна спостерігати віднесення одних і тих же співставних елементів структур до різних видів. 
На основі проведеного аналізу автором запропоновано виокремити такі елементи структури економіки (табл. 1) та визначити відповідні пропорції, які належать до кожної з них.

До основних пропорцій відтворювальної структури такі належать співвідношення:

- співвідношення споживання, відтворення (амортизація) та нагромадження (характеризує можливість стійкого розвитку через оптимальний приріст нагромадження капіталу);

- співвідношення проміжного споживання й доданої вартості (характеризує матеріалоємність виробництва i, відповідно, технологічний рівень виробництва);

- співвідношення рівня оплати праці та валового прибутку, змішаного доходу (відображає відповідність динаміки заробітної плати динаміці ВВП);

- співвідношення виробництва засобів виробництва та предметів споживання (наявність відтворювального ресурсу та стану основних засобів в національній економіці);

- співвідношення галузей матеріального виробництва та інфраструктури (відображає розподіл інвестиційних ресурсів до сфер пріоритетного розвитку через економічні механізми).

Секторально-галузева структура характеризується такими співвідношеннями:

- співвідношення секторів (нефінансові корпорації, фінансові корпорації, сектор загального державного управління, сектор домашніх господарств, сектор некомерційних організацій);

- співвідношення сфер (сфера матеріального виробництва, сфера послуг);

- співвідношення галузей тощо.
Інституційна структура є сукупністю певним чином упорядкованих різнорівневих інститутів, основу якої складають основоположні політичні, соціальні та юридичні правила, які формують основу процесу суспільного відтворення та визначають умови функціонування й розвитку економічних суб'єктів. На їі основі формуються права власності, правовий режим використання ресурсів, правовий режим оподаткування, способи отримання доходів тощо.

Отже, серед основних пропорцій інституціональної структури варто виокремити:

- структуру власності (співвідношення державної, комунальної та приватної власності);

- легальна структура (частка «тіньової» економіки);

- структура конкуренції (частка монополізованого, вільного ринку тощо);

- структура управління (співвідношення державного регулювання та ринкового саморегулювання) тощо.

Територіальна структура характеризує національну економіку як багаторівневу ієрархічну систему, у складі якої можна виділити пропорції, що відображають стан кожної підсистеми на певному рівні:

- міжнародний рівень (характеризує зв'язки національної економіки зі світовою економічною системою);

- макроекономічний рівень (характеризує темпи та пропорції регіонального розвитку національної економіки загалом);

- міжрегіональний рівень (характеризує різноманітні економічні та інші зв'язки між окремими регіонами країни);

\section{Таблиця 1 - Елементи структури економіки та їх характеристика}

\begin{tabular}{|l|l|}
\hline \multicolumn{1}{|c|}{$\begin{array}{c}\text { Елемент структури } \\
\text { екоки }\end{array}$} & \multicolumn{1}{c|}{ Сутність } \\
\hline $\begin{array}{l}\text { Відтворювальна } \\
\text { структура }\end{array}$ & $\begin{array}{l}\text { Співвідношення елементів процесу суспільного відтворення. Ці пропорції } \\
\text { відображають можливості зростання виробництва та його ефективності. }\end{array}$ \\
\hline $\begin{array}{l}\text { Секторально-галузева } \\
\text { структура }\end{array}$ & $\begin{array}{l}\text { Відображає поділ економіки на якісно відмінні складові частини (сектори, сфери, } \\
\text { групи галузей, галузі, міжгалузеві комплекси) та показує співвідношення між ними. }\end{array}$ \\
\hline $\begin{array}{l}\text { Інституціональна } \\
\text { структура }\end{array}$ & $\begin{array}{l}\text { Передбачає певну ієрархію різних інститутів, що впорядковує людські } \\
\text { взаємовідносини. Формування інституціональної ієрархії залежить як від видів } \\
\text { інститутів, так і від рівня охоплення їх дії та тривалості функціонування. }\end{array}$ \\
\hline $\begin{array}{l}\text { Територіальна } \\
\text { структура }\end{array}$ & $\begin{array}{l}\text { Відображає розміщення, просторове поєднання й взаємодію усіх видів економічної } \\
\text { діяльності за окремими територіальними одиницями. }\end{array}$ \\
\hline $\begin{array}{l}\text { Зовнішньоекономічна } \\
\text { структура }\end{array}$ & $\begin{array}{l}\text { Відображає співвідношення експорту та імпорту товарів, послуг, технологій, капіталів } \\
\text { тощо. }\end{array}$ \\
\hline $\begin{array}{l}\text { Секторальна } \\
\text { структура }\end{array}$ & Характеризує економічну структуру за сферами діяльності ііі суб'єктів. \\
\hline $\begin{array}{l}\text { Технологічна } \\
\text { структура }\end{array}$ & Визначається технологічними укладами у структурі національної економіки. \\
\hline Соціальна структура & $\begin{array}{l}\text { Відображає співвідношення між групами населення за рівнем доходів (частка } \\
\text { середнього класу, рівень бідності), рівнем освіти тощо. }\end{array}$ \\
\hline
\end{tabular}

Джерело: складено автором на основі джерела [2; 3; 5] 
- внутрішньорегіональний рівень (характеризує діяльність у межах одного регіону);

- локальний (місцевий) рівень (охоплює господарську діяльність у межах окремої частини регіонального утворення) [4].

Основними пропорціями зовнішньоекономічної структури є співвідношення експорту та імпорту країни, структура безпосередньо експорту та імпорту.

Пропорцією секторальної структури є співвідношення кількості задіяних суб'єктів у різних секторах національної економіки (у первинному, вторинному, третинному, четвертинному, п’ятинному).

Технологічна структура характеризує національну економіку щодо iі відповідності тенденціям науково-технічного розвитку країн світу. Основною пропорцією, яка іiі характеризує, є частка виробленої продукції чи послуг, що відповідають тому чи іншому технологічному укладу.

Пропорції соціальної структури є певною мірою узагальнюючими щодо ефективності структури національної економіки, оскільки характеризує стан економічного й соціального розвитку країни. До основних пропорцій, що ії характеризують, належать:
- співвідношення доходів частки найбагатших і найбідніших громадян;

- частка працездатного населення;

- структура міграції населення;

- рівень зайнятості та безробіття;

- частка середнього класу;

- рівень освіти населення;

- частка сільського та міського населення тощо.

Висновки. Таким чином, економічна система $є$ складною структурою, що сформована з різних елементів, які мають низку компонентів та пропорцій між ними. Пропорції між елементами структури постійно змінюються, що свідчить про динаміку структури, але ці зміни є різними, що приводить до структурних зрушень та формування нової структури економіки. Побудова оптимальної структури економіки, яка б сприяла не лише покращенню економічних показників порівняно з попередніми періодами, але й досягненню потенційно можливого рівня, є головним завданням державного регулювання економіки. Це вимагає максимального врахування наявних пропорцій та взаємозв'язків 3 подальшим впливом на їх зміну задля вироблення ефективної економічної політики.

\section{Список використаних джерел:}

1. Бодров В.Г., Гусєв В.О., Соколова В.О. Управління структурними зрушеннями та інноваційно-інвестиційними процесами в економіці України : навчальний посібник. Київ : вид-во НАДУ, 2011. 284 с.

2. Клімова О.І. Структурні зміни в економіці: основні поняття та види. Збірник наукових праць Черкаського державного технологічного університету. Серія: Економічні науки. Вип. 24 (1). С. 60-65.

3. Шинкарук Л.В. та ін. Структурні трансформації в економіці України: динаміка, суперечності та вплив на економічний розвиток : наукова доповідь. Київ : НАН України, ДУ «Ін-т екон. та прогнозув. НАН України», 2015.304 с.

4. Тищенко О.П. Структуризація національної економіки та теоретичні підходи до управління іiі регіональним розвитком. Ефективна економіка. 2013. № 1. URL: http://www.economy.nayka.com.ua/?op=1\&z=2081.

5. Поченчук Г.М. Інституціональний вимір структурних характеристик економічної системи. Проблеми системного підходу в економічі. 2017. № 6 (62). С. 25-32.

\section{References:}

1. Bodrov V.G., Gusev V.A., and Sokolova O.M. (2011), Upravlinnia strukturnymy zrushenniamy ta innovatsijnoinvestytsijnymy protsesamy v ekonomitsi Ukrainy [Structural Shift Management and Innovation and Investment Processes in the Ukrainian Economy], NADU, Kyiv. Ukraine.

2. Klimova O.I. (2009), "Structural changes in the economy: basic concepts and types", Zbirnyk naukovykh prats' Cherkas'koho derzhavnoho tekhnolohichnoho universytetu. Ser.: Ekonomichni nauky, vol. 24 (1), pp. 60-65.

3. Shinkaruk L.V., Bevz I.A. and Baranovskaya I.V. (2015), Strukturni transformatsii v ekonomitsi Ukrainy: dynamika, superechnosti ta vplyv na ekonomichnyj rozvytok: naukova dopovid' [Structural Transformations in the Ukrainian Economy: Dynamics, Contradictions and Impact on Economic Development: Scientific Report], NAN Ukrainy, DU "In-t ekon. ta prohnozuv.", Kyiv, Ukraine.

4. Tishchenko O.P. (2013) "Structuring the national economy and theoretical approaches to managing its regional development", Efectyvna economika, [Online], vol. 1, available at: http:/www.economy.nayka.com.ua (accessed: 15 July 2013).

5. Pochenchuk G.M. (2017), "Institutional measurement of structural characteristics of the economic system", Problemy systemnoho pidkhodu v ekonomitsi, vol. 6 (62), pp. 25-32.

Derhaliuk Bohdan

National Technical University of Ukraine "Igor Sikorsky Kyiv Polytechnic Institute"

\section{STRUCTURAL ELEMENTS OF ECONOMY AND THEIR PROPORTIONS}

The article examines the essence of the structure of the economy and determines its importance in relation to the dynamics and direction of economic development of the country. It is established that the development of the economic 
system is constantly influenced by a number of internal and external factors that determine its direction and dynamics. Under the influence of the above factors, the structure of the economy is formed-a set of industries, spheres of economic activity, interconnected by the social division of labor, covering the production of goods, exchange, distribution and consumption of them, as well as various organizational forms and institutions in which economic processes occur, economic activity of people in a sure way to organize the economic life of society in order to solve its key problems. The above structure is quite complex and consists of a set of relatively interrelated elements, each of which has a distinct role, but is engaged in the achievement of common goals, while maintaining the immutability of its basic properties under the influence of external and internal factors. Among these elements are identified: reproductive, sectoral, institutional, territorial, foreign economic, sectoral, technological and social structures. In turn, the state of these elements of the structure of the economy is determined by certain proportions. These proportions form the structural model of the economy of a country. The imbalances arising in these proportions lead to a crisis in the structure of the country's economy. But these proportions undergo constant changes, which indicate the dynamics of the structure. These changes are different, which, in turn, leads to structural changes and the formation of a new structure of the economy. That is why the state economic policy of the country should be built taking into account the proportions in the elements of the structure of the economy and accordingly influence their change in order to build an optimal structure of the economy, which would not only contribute to the improvement of economic indicators in comparison with the previous period, but also contribute to the achievement of the potential possible level.

Key words: structure of economy, elements of structure of economy, proportions of structure of economy, etc.

JEL classification: E20, P47. 